\title{
Defining metrics of the Quasi-Biennial Oscillation in global climate models
}

\author{
Verena Schenzinger ${ }^{1}$, Scott Osprey ${ }^{2,1}$, Lesley Gray ${ }^{1}$, and Neal Butchart ${ }^{3}$ \\ ${ }^{1}$ Atmospheric, Oceanic and Planetary Physics, University of Oxford, Oxford, UK \\ ${ }^{2}$ National Centre for Atmospheric Science, Department of Physics, Oxford, UK \\ ${ }^{3}$ Met Office Hadley Centre, Exeter, Devon, UK \\ Correspondence to: Verena Schenzinger (schenzinger@atm.ox.ac.uk)
}

Received: 18 November 2016 - Discussion started: 7 December 2016

Revised: 13 April 2017 - Accepted: 27 April 2017 - Published: 8 June 2017

\begin{abstract}
As the dominant mode of variability in the tropical stratosphere, the Quasi-Biennial Oscillation (QBO) has been subject to extensive research. Though there is a welldeveloped theory of this phenomenon being forced by wavemean flow interaction, simulating the QBO adequately in global climate models still remains difficult. This paper presents a set of metrics to characterize the morphology of the QBO using a number of different reanalysis datasets and the FU Berlin radiosonde observation dataset. The same metrics are then calculated from Coupled Model Intercomparison Project 5 and Chemistry-Climate Model Validation Activity 2 simulations which included a representation of QBOlike behaviour to evaluate which aspects of the QBO are well captured by the models and which ones remain a challenge for future model development.
\end{abstract}

\section{Introduction}

After being referred to as a "mystery or freak" by one of its discoverers (Reed, 1967), the Quasi-Biennial Oscillation (QBO) now is accepted as the dominant pattern of variability in the equatorial stratosphere (Baldwin et al., 2001; Pascoe et al., 2005). Between 3 and $100 \mathrm{hPa}$, zonal wind at the Equator is characterized by a pattern of descending easterly and westerly shear zones, with wind direction changing about every 14 months (see, for example, the ERA-Interim reanalysis and observations in Fig. 1). The earliest regular observations of the equatorial stratosphere and hence the discovery of the QBO are credited to Ebdon (1960) and Reed et al. (1961). Angell and Korshover (1964), who named the phenomenon the "Quasi-Biennial Oscillation", pointed out oscillatory behaviour not only in zonal wind, but also in temperature, total ozone and tropopause height. The regularity of the oscillation makes it the most known repeatable mode of variability in the atmosphere, outside of the diurnal and seasonal cycles. Whether or not the QBO remains as regular in the presentday climate and under future climate change is an outstanding question (Osprey et al., 2016; Newman et al., 2016).

Early attempts to explain the driving mechanisms of the QBO failed in describing one or more of its main features, such as the quasi-biennial periodicity, the downward propagation or the roughly constant amplitude during the descent. Initial thoughts regarding the driving processes involved internal feedbacks, natural atmospheric modes, an unknown external process or a combination of those (Baldwin et al., 2001). The first study to explore possible forcing by gravity waves was by Lindzen and Holton (1968). They showed that vertically propagating waves could provide momentum for the QBO. This theory of wave-mean flow interaction was supported by a laboratory experiment carried out by Plumb and McEwan (1978). They were able to produce a descending oscillation of the mean flow in a large annulus containing a salt-stratified fluid, the first practical demonstration of a laboratory analogue for the QBO. With the development of a theory of equatorial waves in the late 1960s that was observationally confirmed (Maruyama, 1967; Wallace and Kousky, 1968), the work of Lindzen and Holton (1968) could be refined. Holton and Lindzen (1972) simulated a QBO-like oscillation in a simple one-dimensional (1-D) model, driven by vertically propagating Kelvin and Rossby gravity waves that 


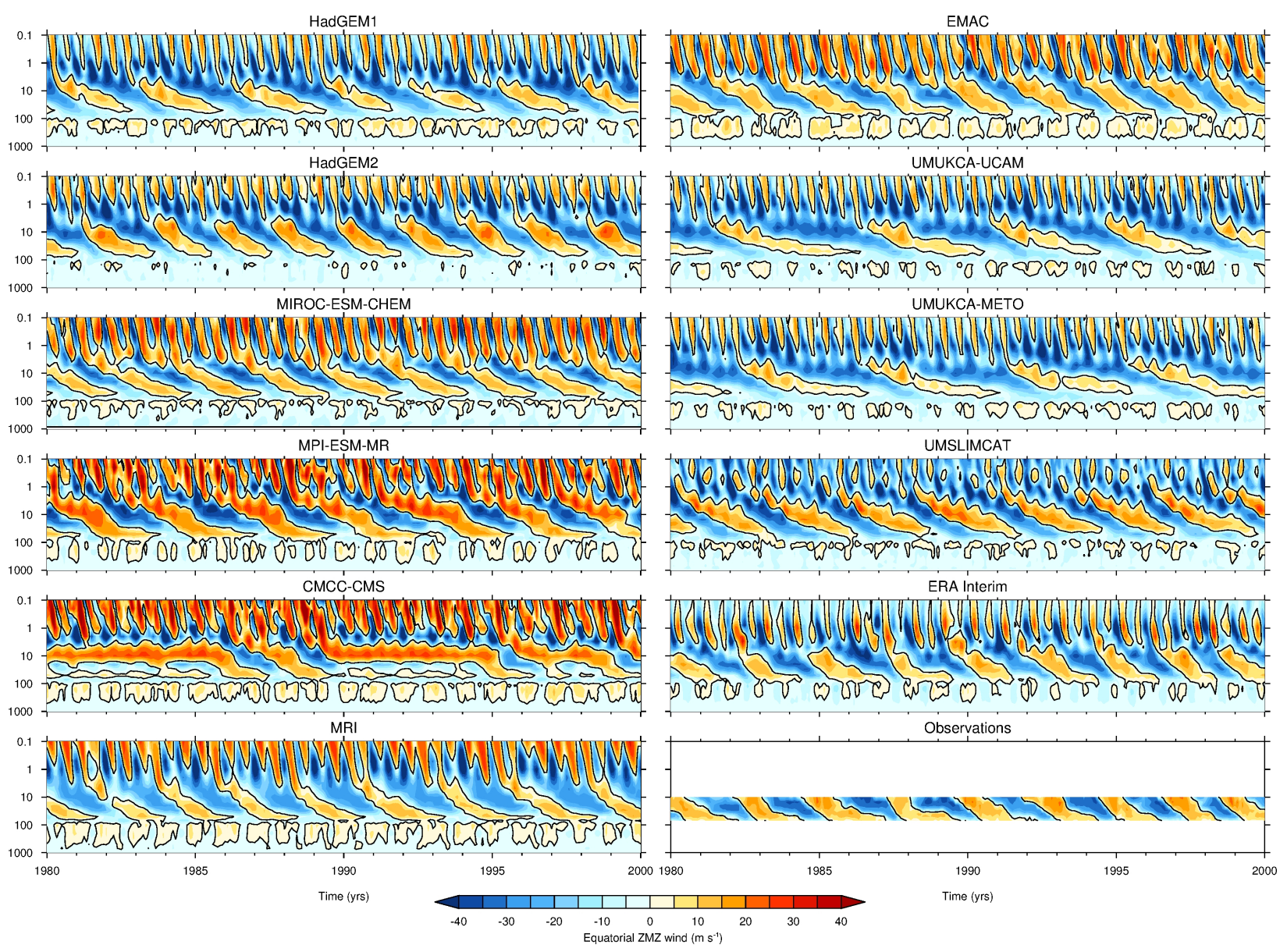

Figure 1. Equatorial zonal mean zonal wind time-height series from models and the ERA-Interim reanalysis, 1980-2000. Easterlies are blue, westerlies red. The zero wind line is shown in black. The observational dataset from the Freie Universität Berlin (2015) is shown on the bottom right for levels $10-70 \mathrm{hPa}$.

contribute westerly and easterly momentum forcing, respectively.

The first successful simulations of a reasonably realistic QBO were achieved in a 2-D model by Gray and Pyle (1989) and in a 3-D global climate model by Takahashi (1996). Follow-on studies describing simulations that captured a QBO were Horinouchi and Yoden (1998), Takahashi (1999), Scaife et al. (2000) and Hamilton et al. (2001). Adequate simulation of the QBO is affected by resolution (horizontal and vertical), parametrized gravity wave forcing from sub-grid-scale waves (Giorgetta et al., 2006) and placement of the model lid (Lawrence, 2001; Osprey et al., 2013). However, there is no simple model configuration that would guarantee a successful QBO simulation and, despite there being a well-established theory of the QBO, not all climate models can produce it. Of the 47 contributions submitted to the Coupled Model Intercomparison Project 5, CMIP5 (World Climate Research Programme, 2010), only 5 have a QBO- like signal (Lott et al., 2014) ${ }^{1}$. In the models submitted to the Chemistry-Climate Model Validation Activity (SPARC CCMVal, 2010) there are 5 out of 14 , with 3 of them variants of the Met Office Unified Model (Butchart et al., 2011).

The aim of this paper is to establish a set of standard metrics that comprehensively characterize the QBO. These metrics were defined to be as simple as possible, yet meaningful in characterizing the QBO morphologically. For robust and simple assessment of the QBO in models and observations, this study focusses on the large-scale morphology of the QBO rather than those (small-scale) dynamical processes involved in maintaining it. Using these characteristics, the performance of 10 historical model simulations is assessed and compared to observations and reanalysis datasets as the starting point of the World Climate Research Programme's (WCRP) Stratosphere-troposphere processes and their role in

\footnotetext{
${ }^{1}$ Of these models, 10 resolve the stratosphere and include nonorographic gravity wave drag (Charlton-Perez et al., 2013), which are necessary ingredients for QBO simulation.
} 
Climate (SPARC) QBO initiative (QBOi $\left.{ }^{2}\right)$ and SPARC Reanalysis Intercomparison Project (S-RIP). The purpose is to provide a benchmark for the current status of the representation of the QBO in global models against which new QBOresolving simulations can be quantified.

\section{Data}

For this study, monthly means of zonally averaged zonal wind and temperature of four CMIP5 and five CCMVal-2 models as well as one from CMIP3 that internally produce a QBO were investigated. Table 1 lists these models and further details. Model data were obtained from the British Atmospheric Data Centre $\left(\mathrm{BADC}^{3}\right)$. For comparison, the Berlin dataset (Freie Universität Berlin, 2015) of equatorial zonal wind from radiosonde observations covering 1956 to 2015 (Canton Island 1956-1967, Gan/Maldives 1967-1975, Singapore 1967-2015) was analysed, as well as several reanalysis datasets (Table 2) made available through the SPARC Reanalysis Intercomparison Project (S-RIP) project ${ }^{4}$. When an average of more than one reanalysis was used, only the three relatively recent products (ERA-Interim, MERRA, JRA55), comprising the years 1979-2009, were employed.

\section{Definition of characteristic metrics}

Figure 1 shows the equatorial zonal mean zonal wind for the different models, the ERA-Interim reanalysis and the FU Berlin dataset. In the models' stratosphere, QBO-like oscillations can be recognized. How much these resemble the observed QBO will be assessed based on a set of characteristic metrics. The most obvious one is the mean period; however, the QBO has a structure in latitude and height and the behaviour of easterly and westerly phases differs. Furthermore, it is not a classic harmonic oscillation with one single restoring force, which leads to a variety of periods (Dunkerton, 2016). There might be an interaction with the semiannual oscillation or the 11-year solar cycle as well as the annual cycle in the troposphere that can influence timing of phase changes and descent of the shear zones. To assess the different aspects of the QBO that are seen in the zonal wind observations, we propose a set of characteristic metrics, including the height of the maximum amplitude, the latitudinal and vertical extent, and the descent rates of each shear zone (Table 3, first row).

Figure 2 shows the process of metric derivation using the reanalyses mean (ERA-Interim, MERRA, JRA55) as an example. Derived values from the individual reanalyses, the FU Berlin dataset and model simulations are provided in Table 3. The metrics are defined as follows.

\footnotetext{
${ }^{2}$ http://users.ox.ac.uk/ astr0092/QBOi.html

${ }^{3}$ http://badc.nerc.ac.uk/home/index.html

${ }^{4}$ http://s-rip.ees.hokudai.ac.jp/
}

- The Fourier transformation of the equatorial zonal mean wind field (Fig. 2, left panel) is calculated. The squares of the amplitudes between 26 and 30 months are added. The height of the maximum amplitude is taken as metric $h_{\max }$.

- At $h_{\max }$, the time series of $\bar{u}$ is used to find the QBO period, defined as the time between every other phase change (Fig. 2, right panel) $)^{5}$. The minimum, maximum and mean of the periods are defined as QBO metrics. The months in which these phase changes occur are used to look for annual synchronization of the QBO (Fig. 6).

- The amplitudes of the easterly/westerly phase in one QBO cycle are defined from the time series as the minimum/maximum wind value of a cycle. The values of each cycle are averaged to give the easterly/westerly amplitude.

- The inverse of the minimum/maximum period defines the upper/lower limit of the QBO Fourier harmonics (Fig. 2, left panel). The sum of the squares of the QBO amplitudes over the square root of the field variance gives the QBO Fourier amplitude. Doing this calculation for each grid point results in the QBO Fourier amplitude latitude-altitude structure (Fig. 2, middle panel).

- The vertical profile at the Equator is calculated as the QBO Fourier amplitude for the zonal wind, averaged between $5^{\circ}$ north and south (Fig. 2, top panel). The vertical extent of the QBO is defined as the full depth at half maximum of the profile; the lowermost depth of the QBO (the lowermost level affected) is defined as the level of $10 \%$ of the maximum amplitude. Using the vertical profile, the value of the previously estimated $h_{\max }$ as the height of the maximum amplitude is validated.

- From the horizontal cross section at the height of the QBO maximum (Fig. 2, bottom panel), the latitudinal extent (width) is defined by the full width at half maximum of a fitting Gaussian. The QBO Fourier amplitude is identified as the maximum amplitude, following Pascoe et al. (2005).

- The development of the profile of equatorial zonal wind serves to identify the descent rate of the shear zones. Figure 3 illustrates the procedure: at each point in time,

\footnotetext{
${ }^{5}$ An alternative way to define a QBO period is presented by Wallace et al. (1993), who use the first two principle component time series of the stratospheric equatorial zonal wind in the approach. This has been applied to the FU Berlin dataset and results for the two methods are within each other's error range: $28.0 \pm 3.6$ vs. $28.2 \pm 4.4$ months. For simplicity, the period metric has been defined from the raw zonal wind data.
} 
Table 1. Climate models used in the study. HadGEM1 was part of CMIP3; MIROC-ESM-CHEM, MPI-ESM-MR, HadGEM2-CC and CMCC-CMS were part of CMIP5; the rest are CCMVal-2 models. CMIP5 models are runs with a coupled ocean; HadGEM1 and the CCMVal-2 models are atmosphere-only runs. The gravity wave (GW) parametrization schemes are based on either the Ultra-Simple Spectral Parametrisation of Warner and McIntyre (2001) (W \& M) or the Doppler Spread Parametrisation scheme of Hines (1997a, b) (Hines).

\begin{tabular}{|c|c|c|c|c|}
\hline Model & Reference & Resolution & GW scheme & Length \\
\hline HadGEM1 & $\begin{array}{l}\text { Osprey et al. (2010) } \\
\text { Hardiman et al. (2010) } \\
\text { Bushell et al. (2010) }\end{array}$ & N96 L60 & $\mathrm{W} \& \mathrm{M}$ & 50 years \\
\hline MIROC-ESM-CHEM & $\begin{array}{l}\text { Watanabe et al. (2011), } \\
\text { Watanabe and Kawatani (2012) }\end{array}$ & T42 L68 & Hines & 156 years \\
\hline MPI-ESM-MR & $\begin{array}{l}\text { Schmidt et al. (2013), } \\
\text { Krismer and Giorgetta (2014) }\end{array}$ & T63 L95 & Hines & 156 years \\
\hline HadGEM2-CC & $\begin{array}{l}\text { Osprey et al. (2013) } \\
\text { Hardiman et al. (2012) }\end{array}$ & $1.25^{\circ} \times 1.875^{\circ} \mathrm{L} 60$ & $\mathrm{~W} \& \mathrm{M}$ & 374 years \\
\hline CMCC-CMS & $\begin{array}{l}\text { Manzini et al. (2006), } \\
\text { Giorgetta et al. (2006) }\end{array}$ & T63 L95 & Hines & 156 years \\
\hline EMAC & Jöckel et al. (2006) & T42 L90 & Hines & 41 years \\
\hline MRI & $\begin{array}{l}\text { Shibata and Deushi (2008a), } \\
\text { Shibata and Deushi (2008b) }\end{array}$ & T42 L68 & Hines & 47 years \\
\hline UMSLIMCAT & Tian and Chipperfield (2005) & $2.50^{\circ} \times 3.75^{\circ} \mathrm{L} 64$ & $\mathrm{~W} \& \mathrm{M}$ & 55 years \\
\hline UMUKCA-METO & Morgenstern et al. (2009) & $2.50^{\circ} \times 3.75^{\circ} \mathrm{CP} 60$ & $\mathrm{~W} \& \mathrm{M}$ & 47 years \\
\hline UMUKCA-UCAM & Morgenstern et al. (2009) & $2.50^{\circ} \times 3.75^{\circ} \mathrm{CP} 60$ & $\mathrm{~W} \& \mathrm{M}$ & 45 years \\
\hline
\end{tabular}

Table 2. Reanalysis datasets used in the study. The period is 1979-2009 for all reanalyses except ERA40, which covers 1958-2001.

\begin{tabular}{lll}
\hline Reanalysis & Reference & Resolution of forecast model \\
\hline ERA40 & Uppala et al. (2005) & $\mathrm{T}_{\mathrm{L}} 159$ and N80 reduced Gaussian, L60 \\
ERA-Interim & Uppala et al. (2005) & $\mathrm{T}_{\mathrm{L}} 255$ and N128 reduced Gaussian, L60 \\
MERRA & Rienecker et al. (2011) & $0.66^{\circ}$ lon $\times 0.5^{\circ}$ lat; 72 sigma levels \\
JRA25 & Onogi et al. (2007) & T106 L40 \\
JRA55 & Kobayashi et al. (2015) & $\mathrm{T}_{\mathrm{L}}$ 319 L60 \\
CFSR & Saha et al. (2010) & T382 L64 \\
NCEP1 & Kalnay et al. (1996) & T62 L28 \\
& Kistler et al. (2001) & \\
NCEP2 & Kanamitsu et al. (2002) & T62 L28 \\
\hline
\end{tabular}

the height of the sign change $(\bar{u}=0)$ of the wind profile is found by linear interpolation between two $\bar{u}$ values of opposite sign at adjacent grid points. The difference between the heights $\Delta h=h_{t+1}-h_{t}$, divided by the time resolution $\Delta t=1$ month, gives the descent rate at this time step. The mean of the descent rates between 10 and $70 \mathrm{hPa}$ is calculated separately for the two shear zones as the mean over all values for a descending easterly/westerly.

The metrics for the temperature field are derived in an analogous way from the Fourier spectrum of the $T$ time series. QBO temperature characteristics include the maximum Fourier amplitude, height of this maximum, depth of the QBO, and latitudinal and vertical extent.

\section{Error estimations}

For metrics that are calculated as the mean over various cycles, the standard deviation $\left(\sigma^{2}=\frac{1}{n} \sum_{i=1}^{n}\left(x_{i}-\bar{x}\right)\right)$ of the mean value is given as an error estimate. These are the mean period, the easterly/westerly wind amplitudes and the easterly/westerly descent rates.

The error of the minimum and maximum periods is established following the method of surrogate time series presented by Christiansen (2010). First, the wind time series at $h_{\text {max }}$ is subdivided into separate QBO cycles, with each cycle beginning at the minimum wind value between every other sign change of the wind. A long pseudo-QBO time series is constructed by concatenating 1000 randomly chosen cycles. From this time series, 100 samples of the same length as the original dataset are taken as surrogate QBO time series. The minimum and maximum periods of these are estimated and 


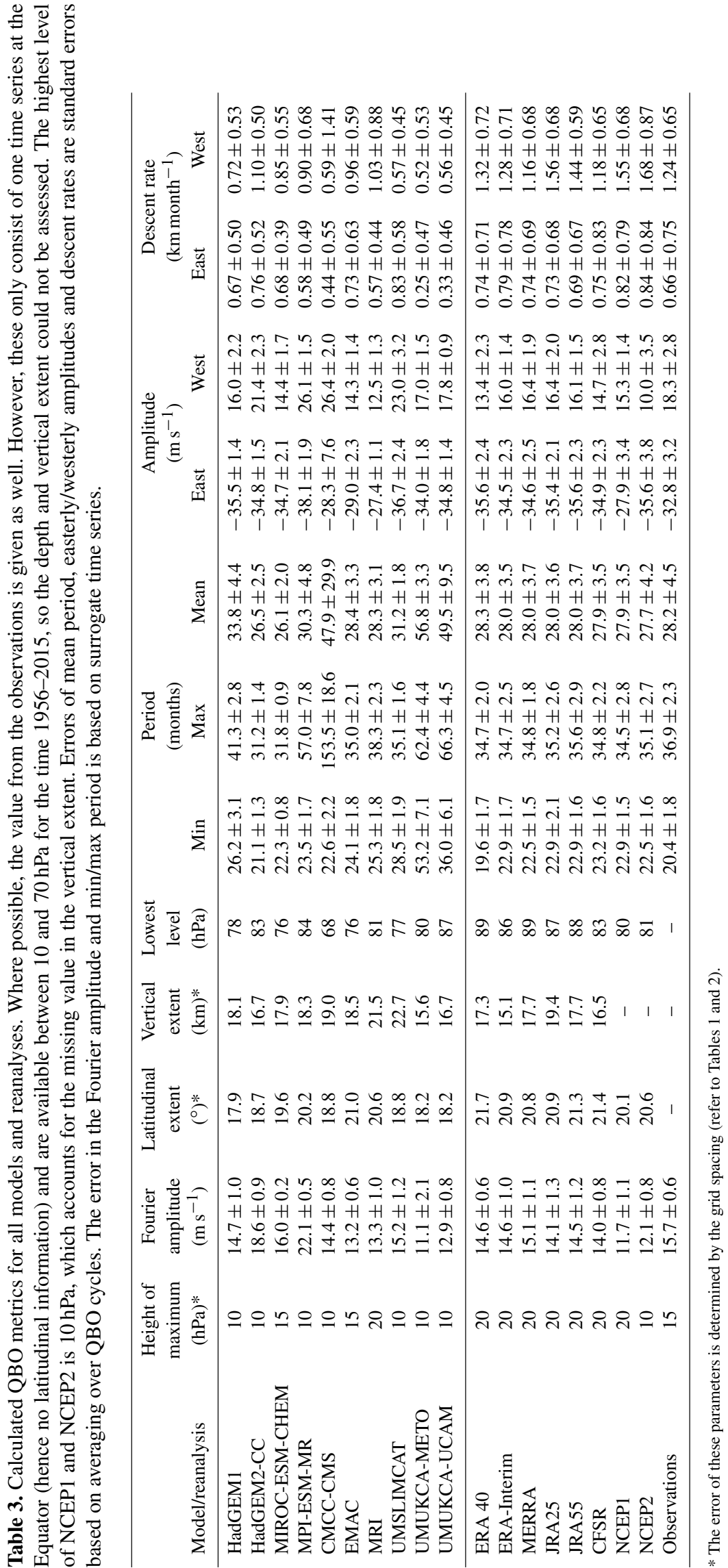



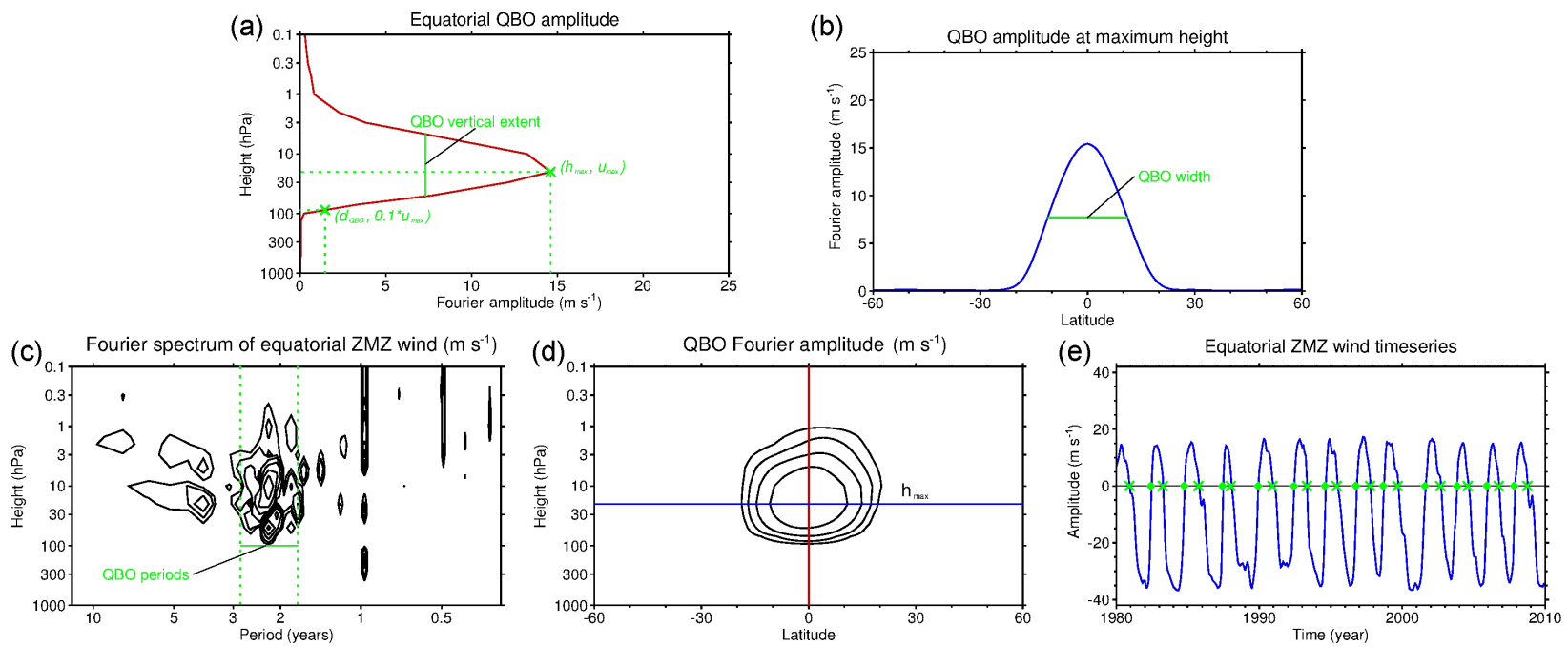

Figure 2. Derivation of QBO $\bar{u}$ characteristic metrics, exemplified with the reanalyses mean: bottom row: mean Fourier spectrum (c) of equatorial zonal mean zonal wind. Contours are drawn at 1,2, 4, 8 and $16 \mathrm{~m} \mathrm{~s}^{-1}$. The Fourier harmonics around 2 years are averaged to give the latitude-altitude QBO amplitude (d, same contours). From the $\bar{u}$ time series at $h_{\max }$ (e), the period of each single QBO cycle is calculated and the easterly/westerly amplitudes are identified. From the latitude-altitude QBO structure, a cross section at the Equator (red) is taken to derive the QBO height profile (a) and one at $20 \mathrm{hPa}$ (blue) for the latitude profile (b). From the height profile, the vertical extent, the depth $d_{\mathrm{QBO}}$ as well as the maximum Fourier amplitude $\left(u_{\max }\right)$ can be identified. The latitude cross section at $h_{\max }$, where the equatorial QBO Fourier amplitude peaks, serves to define the latitudinal extent of the QBO.
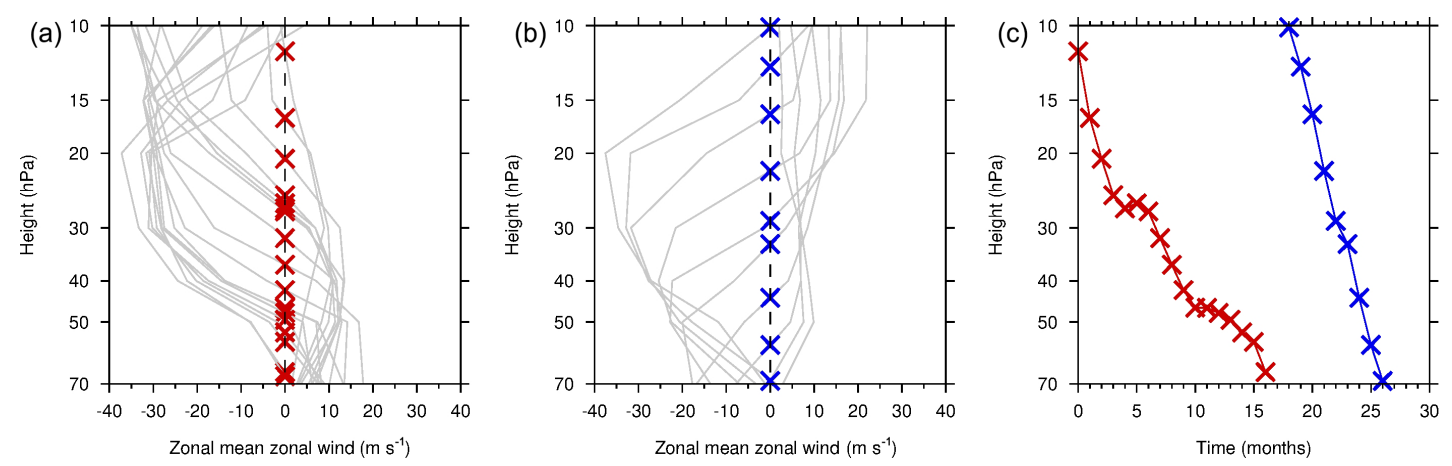

Figure 3. Equatorial $\bar{u}$ profiles in consecutive months for descending easterly (left) and westerly (middle) shear zones from the FU Berlin observations (1964-1966 cycle). The heights of phase change in each month are shown in red/blue and are displayed in the right panel.

the standard deviation is taken as the error estimate for the values. The error of the Fourier amplitude is calculated in the same way: first, the Fourier spectrum is calculated as in calculating the metric and the standard deviation of the 100 samples is used as an error estimate for the Fourier amplitude.

The surrogate method unfortunately does not work where no clear QBO cycle can be defined - that is at levels below $\sim 70 \mathrm{hPa}$ or above $\sim 10 \mathrm{hPa}$, or further away from the Equator. Errors in metrics that are based on the Fourier amplitude outside the area dominated by the QBO (latitudinal and vertical extent, height of maximum, lowermost affected level) are mostly determined by the horizontal and vertical resolution of the model/reanalysis, which are given in Tables 1 and 2.

\section{Model performance}

Tables 3 and 4 list the characteristic metrics for all CMIP5 and CCMVal-2 models that have an internally generated QBO, for comparison with the reanalysis datasets and FUB observations (where possible). Table 5 compares the multimodel mean and the mean of the three most recent reanalyses. Figure 4 shows the multi-model and multi-reanalysis mean latitude-altitude QBO amplitude.

The success of QBO simulation in global climate models (GCMs) is noticeable: most models represent the wind amplitude well compared to reanalyses and observations for both easterly and westerly QBO phases. Apart from three models (CMCC-CMS, UMUKCA-METO and UMUKCAUCAM), the range of QBO periods is realistic (Table 3), with 
Table 4. Characteristic QBO metrics calculated from the zonal mean temperature. Values for models and reanalyses are listed; there is no comparable observational dataset.

\begin{tabular}{lccccc}
\hline Model/reanalysis & $\begin{array}{c}\text { Height of } \\
\text { maximum } \\
(\mathrm{hPa})^{*}\end{array}$ & $\begin{array}{c}\text { Fourier } \\
\text { amplitude } \\
(\mathrm{K})\end{array}$ & $\begin{array}{c}\text { Latitudinal } \\
\text { extent }\left(^{\circ}\right)^{*}\end{array}$ & $\begin{array}{c}\text { Vertical } \\
\text { extent }(\mathrm{km})^{*}\end{array}$ & $\begin{array}{c}\text { Lowest } \\
\text { level } \\
(\mathrm{hPa})^{*}\end{array}$ \\
\hline HadGEM1 & 15 & $0.7 \pm 0.1$ & 12.9 & 20.0 & 89 \\
HadGEM2-CC & 6 & $1.0 \pm 0.1$ & 14.4 & 19.2 & 96 \\
MIROC-ESM-CHEM & 7 & $1.4 \pm 0.0$ & 13.8 & 16.3 & 69 \\
MPI-ESM-MR & 5 & $1.7 \pm 0.0$ & 15.2 & 20.8 & 82 \\
CMCC-CMS & 5 & $1.1 \pm 0.1$ & 16.0 & 22.9 & 85 \\
EMAC & 20 & $1.2 \pm 0.1$ & 15.7 & 17.7 & 85 \\
MRI & 30 & $0.9 \pm 0.1$ & 15.2 & 19.6 & 97 \\
UMSLIMCAT & 20 & $1.0 \pm 0.1$ & 13.2 & 21.3 & 85 \\
UMUKCA-METO & 30 & $0.7 \pm 0.1$ & 12.8 & 19.6 & 113 \\
UMUKCA-UCAM & 30 & $0.8 \pm 0.1$ & 13.6 & 18.5 & 115 \\
\hline ERA 40 & 30 & $1.3 \pm 0.1$ & 16.2 & 14.2 & 97 \\
ERA-Interim & 30 & $1.3 \pm 0.1$ & 16.8 & 14.9 & 89 \\
MERRA & 30 & $1.3 \pm 0.1$ & 16.8 & 14.8 & 88 \\
JRA25 & 30 & $1.1 \pm 0.2$ & 15.8 & 17.4 & 89 \\
JRA55 & 30 & $1.3 \pm 0.1$ & 16.9 & 13.7 & 88 \\
CFSR & 20 & $1.2 \pm 0.1$ & 17.4 & 15.2 & 85 \\
NCEP1 & 30 & $0.8 \pm 0.1$ & 15.3 & - & 85 \\
NCEP2 & 20 & $0.8 \pm 0.1$ & 27.7 & - & 87 \\
\hline
\end{tabular}

* The error of these parameters is determined by the grid spacing (refer to Tables 1 and 2).

Table 5. Characteristic QBO metrics in reanalyses and models. The mean and \pm 1 standard deviation of the metrics in Tables 3 and 4 are shown. The multi-model mean was calculated from all models (* excluding CMCC-CMS and both UMUKCA models for obvious shortcomings in QBO modelling; Fig. 1), the reanalysis mean from the most recent datasets, namely ERA-Interim, MERRA and JRA55.

\begin{tabular}{lrrr}
\hline ZM zonal wind & Model mean & Model mean (ex) & Reanalysis mean \\
\hline Height of maximum $(\mathrm{hPa})$ & $12 \pm 4$ & $13 \pm 4$ & $20 \pm 0$ \\
Fourier amplitude $\left(\mathrm{m} \mathrm{s}^{-1}\right)$ & $15.1 \pm 3.2$ & $16.3 \pm 3.5$ & $14.8 \pm 0.3$ \\
Latitudinal extent $\left(^{\circ}\right)$ & $19.2 \pm 1.1$ & $19.7 \pm 1.2$ & $21.0 \pm 0.3$ \\
Vertical extent $(\mathrm{km})$ & $18.5 \pm 2.2$ & $18.5 \pm 1.6$ & $16.8 \pm 1.5$ \\
Lowest level $(\mathrm{hPa})$ & $79 \pm 5$ & $80 \pm 4$ & $88 \pm 2$ \\
Mean period (months) & $35.9 \pm 11.2$ & $28.9 \pm 2.8$ & $28.0 \pm 0.0$ \\
Min period (months) & $28.3 \pm 9.7$ & $23.8 \pm 1.9$ & $22.7 \pm 0.2$ \\
Max period (months) & $55.2 \pm 36.9$ & $39.1 \pm 9.6$ & $35.0 \pm 0.5$ \\
Amplitude easterly & $-33.3 \pm 3.7$ & $-33.3 \pm 4.1$ & $-34.0 \pm 1.9$ \\
Amplitude westerly & $18.9 \pm 5.0$ & $17.5 \pm 5.2$ & $15.8 \pm 0.8$ \\
Descent rate easterly & $0.6 \pm 0.2$ & $0.7 \pm 0.1$ & $0.7 \pm 0.0$ \\
Descent rate westerly & $0.8 \pm 0.2$ & $0.9 \pm 0.1$ & $1.3 \pm 0.1$ \\
\hline ZM temperature & & & \\
\hline Height of maximum $(\mathrm{hPa})$ & $17 \pm 11$ & $14 \pm 10$ & $30 \pm 0$ \\
Fourier amplitude $\left(\mathrm{m} \mathrm{s}{ }^{-1}\right)$ & $1.1 \pm 0.3$ & $1.2 \pm 0.4$ & $1.3 \pm 0.0$ \\
Latitudinal extent $\left({ }^{\circ}\right)$ & $14.3 \pm 1.2$ & $14.5 \pm 1.0$ & $16.9 \pm 0.0$ \\
Vertical extent $(\mathrm{km})$ & $19.6 \pm 1.9$ & $18.9 \pm 1.6$ & $14.5 \pm 0.7$ \\
Lowest level (hPa) & $92 \pm 14$ & $86 \pm 10$ & $88 \pm 1$ \\
\hline
\end{tabular}



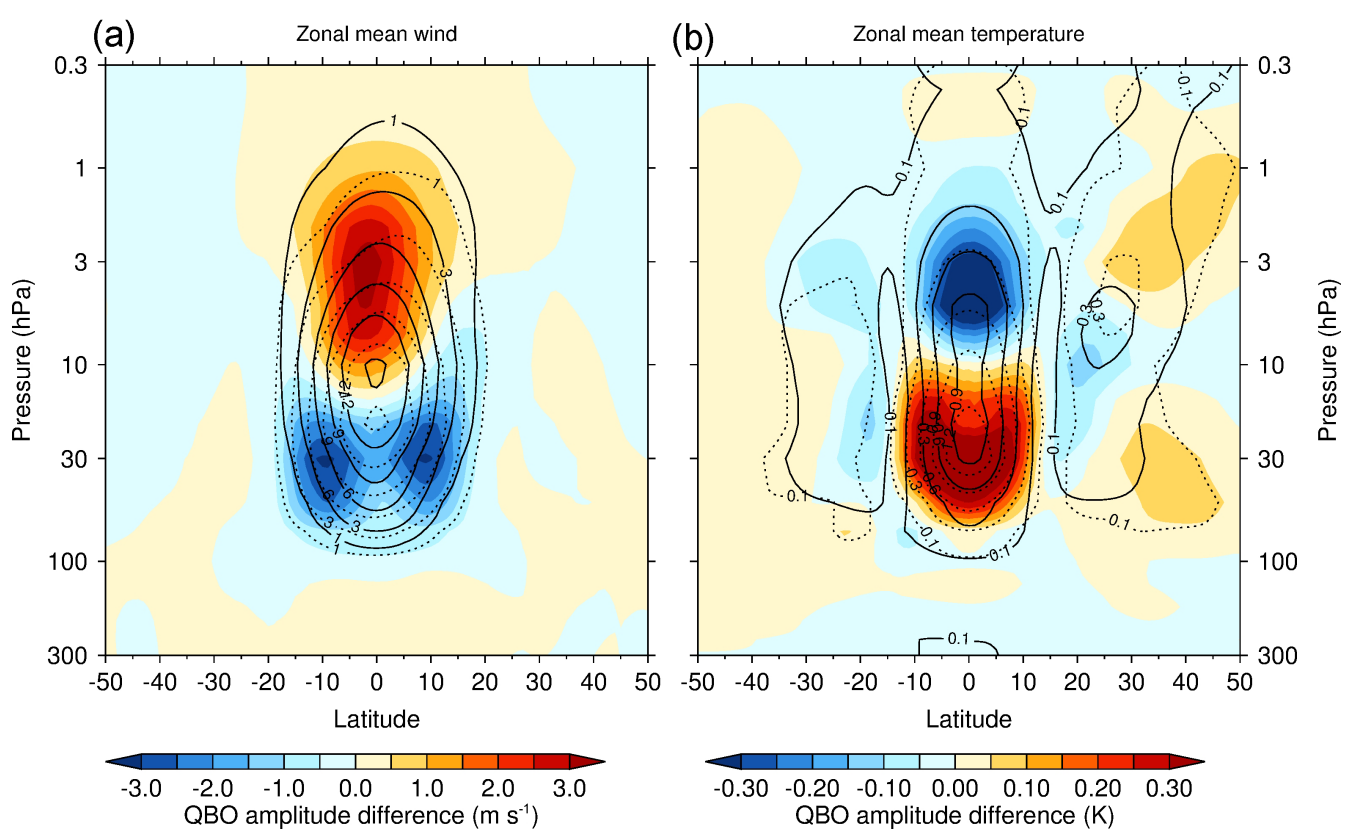

Figure 4. Comparison of QBO amplitudes in $u$ (left) and $T$ (right) from models (solid contours) and reanalyses (dotted contours). The colours show the models-reanalyses difference, with blue depicting an underestimation by models and red an overestimation.

the multi-model mean not being significantly different from the observations and reanalysis mean (Table 5).

A common model bias is a QBO that peaks slightly too high and does not descend low enough, as seen in Fig. 4. This indicates that the whole QBO structure on average is shifted slightly upwards. Even at the height of the maximum QBO amplitude, the simulated QBOs are too narrow in their latitudinal extent (Table 5). The reanalyses that resolve the atmosphere up to at least $1 \mathrm{hPa}$ (all except NCEP1/NCEP2) consistently show the maximum QBO at $20 \mathrm{hPa}$, which is broadly in agreement with the FUB observations, given that the $15 \mathrm{hPa}$ level is not included in the reanalyses.

In the temperature field, half of the models peak at a realistic height $(20-30 \mathrm{hPa})$, whereas the other half peaks too high ( $\sim 5 \mathrm{hPa}$ ), which leads on average to an elongated structure in height for the QBO temperature amplitude (Fig. 4). Again, the difference between the model and the reanalysis mean shows a shift of the QBO structure upwards. Additionally, there is a slight overestimation of the QBO temperature amplitude at subtropical latitudes $\left(15-30^{\circ}\right)$ in the models. Exclusion of models with obvious shortcomings in QBO modelling as seen by unrealistic periods does not significantly improve these biases (Table 5).

There is a slight asymmetry in the descent rates of easterly and westerly shear zones in models, but it is not as pronounced as in the observations/reanalyses, where the westerlies descend about twice as fast as the easterlies. Figure 5 shows the easterly and westerly descent rates for each model and reanalysis dataset as well as the multi-model/reanalysis mean and standard deviations. Even the model with the

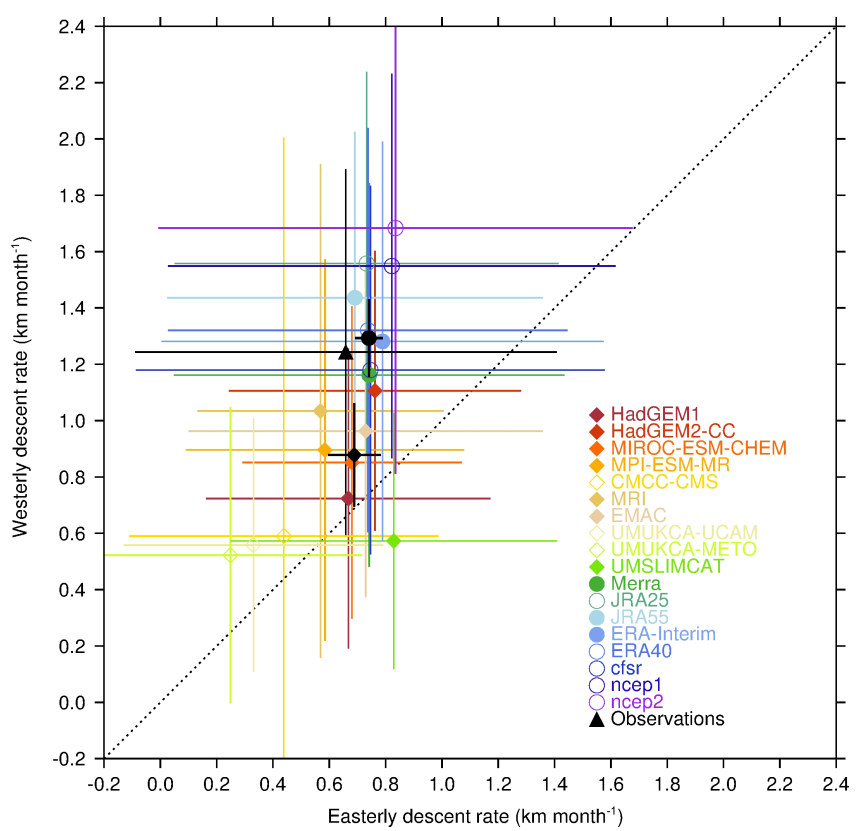

Figure 5. QBO easterly and westerly descent rates in models and reanalyses. The symbols (diamonds for models, circles for reanalyses and triangle for observations) show the mean and standard deviation within each dataset. The filled symbols contribute to the model/reanalysis mean as shown with the black diamond/circle. The dotted line represents equal descent rates for both shear zones as orientation. 

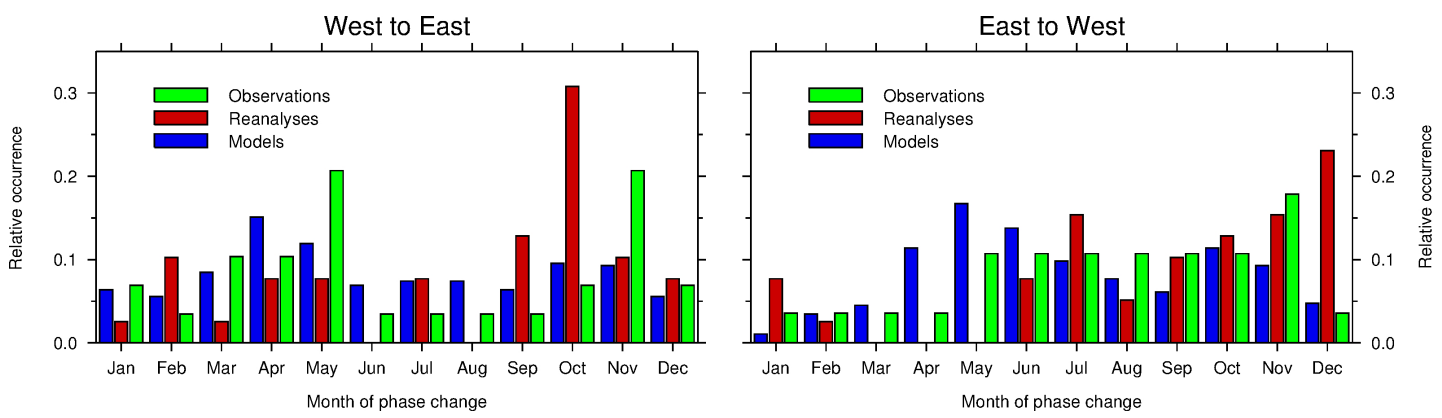

Figure 6. Timing of phase change in models (blue, excluding CMCC-CMS and both UMUKCA models), FUB observations (green) and reanalyses (red). There are 407/29/39 west-east changes (distribution of relative occurrence in the left panel) and 411/28/39 east-west changes taken into account for models/observations/reanalyses.

fastest descending westerlies still has a slower descent rate than the observations and the slowest reanalysis dataset. Most of the models have comparable westerly and easterly descent rates, with UMSLIMCAT even reversing the asymmetry towards faster easterlies. While within reanalyses and the FUB observations, the standard deviation in the easterly descent rate is usually slightly larger than in the westerly descent rate, the inter-model/reanalysis discrepancy is higher for descending westerlies. Models show similar standard deviations for both westerly and easterly descent rates, which can also be seen in a more uniform descent of both shear zones and less prominent stalling features compared to the observations (Fig. 1).

Figure 6 shows the timing of the phase change at the height of the maximum QBO amplitude. For both west to east and east to west transitions, there is a seasonal modulation in the models, with more changes occurring in boreal spring and autumn, but this modulation is not as prominent as in the FUB observations, where west to east transitions are favoured in May and November and east to west transitions are slightly more common in November. Reanalyses favour west to east transitions in October and east to west transitions in December. However, with only 29 FUB observational cycles and $39(3 \times 13)$ in total in the reanalyses to compare, no conclusive statement about the significance of the difference between models and reanalyses/observations can be made. It is, however, intriguing that the distributions of the west-east and east-west transitions look similar in the models but not in the observations/reanalyses.

\section{Discussion and conclusion}

The representation of the stratospheric zonal mean wind and temperature fields in 10 models, 8 reanalysis datasets and the FU Berlin observations (wind only) was assessed in this paper. It is a positive development that an increasing number of global climate models resolve the stratosphere well enough to show an oscillation in zonal mean zonal wind that resembles the observed QBO.
A set of metrics to characterize the quality of these simulations was established and the model performance was evaluated using reanalyses and the FUB observational radiosonde dataset as a reference. Some typical features of the QBO are well represented, such as the asymmetry in easterly/westerly amplitude, the latitudinal confinement around the Equator and the vertical extent. Apart from three models, the mean period and its variability are captured well. However, the QBO in all models is shifted upwards in height compared to reanalyses and narrows in latitude in the lower stratosphere more strongly than the reanalyses (Fig. 4). Even at the height of the maximum QBO, the modelled QBOs are too narrow, which suggests that there are shortcomings in modelling the factors, which influence the width as identified by Haynes (1998), such as the depth scale and the radiative damping. The parametrization of the gravity wave sources or the width of the inter-tropical convergence zone might play a role as well. However, the disagreement between reanalyses is also greatest at low latitudes, as noted by Kawatani et al. (2016), a finding they explain by the small equatorial Coriolis parameter and sparse observations.

The discrepancy between the timing of phase transitions in the reanalyses and observations (Fig. 6) was also pointed out by Kawatani et al. (2016). Model behaviour differs even more from the observations, with a similar phase transition distribution for both east-west and west-east transitions. Kawatani et al. (2016) suggest that weak forcing by resolved waves contributes to the bias in reanalysis, a mechanism that might also lead to the discrepancy in models. Furthermore, parametrized gravity waves in the models used in this study are not coupled to the main generation processes in the atmosphere, such as tropical convection, which might explain why the annual variation in phase transitions is not as prominent as in the observations.

Insufficient wave forcing might also be responsible for the lack of a difference between easterly and westerly descent rates. In observations, westerlies descend on average about twice as fast as easterlies, whereas in models the difference in rates is not significant, with the westerlies descending too 
slowly. The standard deviation of the multi-reanalysis mean is higher for westerly than for easterly descent rates, a result that also points towards disagreement in the underlying westerly forcing.

To address the mechanisms driving the QBO's generation in models as well as its basic morphology will require in any future analysis additional data on the momentum budget in the tropical stratosphere. In particular, wave forcing should be decomposed into resolved and parametrized waves and a distinction made between horizontal and vertical components of momentum fluxes.

In summary, there has been substantial improvement in simulating the tropical stratosphere in global climate models, with QBO-like oscillations being represented in a growing number of models. The characteristic metrics defined here present the possibility of quickly assessing the quality of a simulation. With improving model resolution and (concomitantly) the representation of wave forcing, GCMs are very likely to simulate a more realistic QBO.

Data availability. CMIP5 and CCMVal-2 climate model data were downloaded from the British Atmospheric Data Centre (BADC); HadGEM1 data can be obtained from Scott Osprey. For reanalysis data, please contact Masatomo Fujiwara, who prepared them for the SPARC reanalysis intercomparison project (S-RIP), or the respective centre as listed here http://s-rip.ees.hokudai.ac.jp/resources/ links.html.

\section{The Supplement related to this article is available online at https://doi.org/10.5194/gmd-10-2157-2017- supplement.}

Competing interests. The authors declare that they have no conflict of interest.

Acknowledgements. We acknowledge the World Climate Research Programme's Working Group on Coupled Modelling, which is responsible for CMIP, and we thank the climate modelling groups for producing and making available their model output. We thank the modelling groups of the SPARC Chemistry-Climate Model Validation (CCMVal-2) for producing and making available their model output. We thank the British Atmospheric Data Centre (BADC) for providing access to CMIP5 and CCMVal-2 data and the SPARC reanalysis intercomparison project (S-RIP) for the reanalysis datasets.

S. Osprey and L. Grey would like to to acknowledge funding from National Environment Research Council projects QBOnet (NE/M005828/1) and GOTHAM (NE/P006779/1). N. Butchart was supported by the Joint UK BEIS/DefraMet Office Hadley Centre Climate Programme (GA01101). The authors would also like to thank Adam Scaife, Andrew Bushell, Jeff Knight and Martin Andrews for their valuable contributions to early discussions helping to motivate this study. We thank James Anstey, Kevin Hamilton, Thomas Krismer, John McCormack, Marv Geller and
Tiehan Zou for early discussions on and contributions to the SPARC-QBOi questionnaire.

Edited by: R. Neale

Reviewed by: three anonymous referees

\section{References}

Angell, J. K. and Korshover, J.: Quasi-biennial variations in temperature, total ozone and tropopause height, J. Atmos. Sci., 21, 479-492, 1964.

Baldwin, M. P., Gray, L. J., Dunkerton, T. J., Hamilton, K., Haynes, P. H., Randel, W. J., Holton, J. R., Alexander, M. J., Hirota, I., Horinouchi, T., Jones, D. B. A., Kinnersley, J. S., Marquardt, C., Sato, K., and Takahashi, M.: The quasi-biennial oscillation, Rev. Geophys., 39, 179-229, https://doi.org/10.1029/1999RG000073, 2001.

Bushell, A. C., Jackson, D. R., Butchart, N., Hardiman, S. C., Hinton, T. J., Osprey, S. M., and Gray, L. J.: Sensitivity of GCM tropical middle atmosphere variability and climate to ozone and parameterized gravity wave changes, J. Geophys. Res.-Atmos., 115, D15101, https://doi.org/10.1029/2009JD013340, 2010.

Butchart, N., Charlton-Perez, A. J., Cionni, I., Hardiman, S. C., Haynes, P. H., Krüger, K., Kushner, P. J., Newman, P. A., Osprey, S. M., Perlwitz, J., Sigmond, M., Wang, L., Akiyoshi, H., Austin, J., Bekki, S., Baumgaertner, A., Braesicke, P., Brühl, C., Chipperfield, M., Dameris, M., Dhomse, S., Eyring, V., Garcia, R., Garny, H., Jöckel, P., Lamarque, J.-F., Marchand, M., Michou, M., Morgenstern, O., Nakamura, T., Pawson, S., Plummer, D., Pyle, J., Rozanov, E., Scinocca, J., Shepherd, T. G., Shibata, K., Smale, D., Teyssèdre, H., Tian, W., Waugh, D., and Yamashita, Y.: Multimodel climate and variability of the stratosphere, J. Geophys. Res.-Atmos., 116, D05102, https://doi.org/10.1029/2010JD014995, 2011.

Charlton-Perez, A. J., Baldwin, M. P., Birner, T., Black, R. X., Butler, A. H., Calvo, N., Davis, N. A., Gerber, E. P., Gillett, N., Hardiman, S., Kim, J., Krüger, K., Lee, Y.-Y., Manzini, E., McDaniel, B. A., Polvani, L., Reichler, T., Shaw, T. A., Sigmond, M., Son, S.-W., Toohey, M., Wilcox, L., Yoden, S., Christiansen, B., Lott, F., Shindell, D., Yukimoto, S., and Watanabe, S.: On the lack of stratospheric dynamical variability in low-top versions of the CMIP5 models, J. Geophys. Res.-Atmos., 118, 2494-2505, 2013.

Christiansen, B.: Stratospheric Bimodality: Can the Equatorial QBO Explain the Regime Behaviour of the NH Winter Vortex?, J. Climate, 23, 3953-3966, 2010.

Dunkerton, T. J.: The Quasi-Biennial Oscillation of 2015-16: Hiccup or Death Spiral?, Geophys. Res. Lett., 43, 10547-10552, 2016.

Ebdon, R. A.: Notes on the wind flow at $50 \mathrm{mb}$ in tropical and subtropical regions in January 1957 and in 1958, Q. J. Roy. Meteor. Soc., 86, 540-542, 1960.

Freie Universität Berlin: The Quasi-Biennial-Oscillation (QBO) Data Serie, available at: http://www.geo.fu-berlin.de/en/met/ag/ strat/produkte/qbo/ (last access: 1 July 2016), 2015.

Giorgetta, M. A., Manzini, E., Roeckner, E., Esch, M., and Bengtsson, L.: Climatology and Forcing of the Quasi-Biennial Oscil- 
lation in the MAECHAM5 Model, J. Climate, 19, 3882-3901, 2006.

Gray, L. J. and Pyle, J. A.: A two-dimensional model of the quasibiennial oscillation in ozone, J. Atmos. Sci., 56, 203-220, 1989.

Hamilton, K., Wilson, R. J., and Hemler, R. S.: Spontaneous Stratospheric QBO-like Oscillations Simulated by the GFDL SKYHI General Circulation Model, J. Atmos. Sci., 58, 3271-3292, 2001.

Hardiman, S. C., Butchart, N., Osprey, S. M., Gray, L. J., Bushell, A. C., and Hinton, T. J.: The Climatology of the Middle Atmosphere in a Vertically Extended Version of the Met Office's Climate Model. Part I: Mean State, J. Atmos. Sci., 67, 1509-1525, 2010.

Hardiman, S. C., Butchart, N., Hinton, T. J., Osprey, S. M., and Gray, L. J.: The Effect of a Well-Resolved Stratosphere on Surface Climate: Differences between CMIP5 Simulations with High and Low Top Versions of the Met Office Climate Model, J. Climate, 25, 7083-7099, 2012.

Haynes, P. H.: The latitudinal structure of the quasi-biennial oscillation, Q. J. Roy. Meteorol. Soc., 124, 2645-2670, 1998.

Hines, C. O.: Doppler-spread parameterization of gravity wave momentum deposition in the middle atmosphere. Part 1: Basic formulation, J. Atmos. Sol.-Terr. Phys., 59, 371-386, 1997a.

Hines, C. O.: Doppler-spread parameterization of gravity wave momentum deposition in the middle atmosphere. Part 2: Broad and quasi-monochromatic spectra, and implementation, J. Atmos. Sol.-Terr. Phys., 59, 387-400, 1997 b.

Holton, J. R. and Lindzen, R. S.: An updated theory for the quasibiennial cycle of the tropical stratosphere, J. Atmos. Sci., 29, 1076-1080, 1972.

Horinouchi, T. and Yoden, S.: Wave-Mean Flow Interaction Associated with a QBO-like Oscillation Simulated in a Simplified GCM, J. Atmos. Sci., 55, 502-526, 1998.

Jöckel, P., Tost, H., Pozzer, A., Brühl, C., Buchholz, J., Ganzeveld, L., Hoor, P., Kerkweg, A., Lawrence, M. G., Sander, R., Steil, B., Stiller, G., Tanarhte, M., Taraborrelli, D., van Aardenne, J., and Lelieveld, J.: The atmospheric chemistry general circulation model ECHAM5/MESSy1: consistent simulation of ozone from the surface to the mesosphere, Atmos. Chem. Phys., 6, 50675104, https://doi.org/10.5194/acp-6-5067-2006, 2006.

Kalnay, E., Kanamitsu, M., Kistler, R., Collins, W., Deaven, D., Gandin, L., Iredell, M., Saha, S., White, G., Woollen, J., Zhu, Y., Leetmaa, A., and Reynolds, R.: The NCEP/NCAR 40-Year Reanalysis Project, B. Am. Meteorol. Soc., 77, 437-471, 1996.

Kanamitsu, M., Ebisuzaki, W., Woollen, J., Yang, S.-K., Hnilo, J. J., Fiorino, M., and Potter, G. L.: NCEP-DOE AMIP-II Reanalysis (R-2), B. Ame. Meteorol. Soc., 83, 1631-1643, 2002.

Kawatani, Y., Hamilton, K., Miyazaki, K., Fujiwara, M., and Anstey, J. A.: Representation of the tropical stratospheric zonal wind in global atmospheric reanalyses, Atmos. Chem. Phys., 16, 6681-6699, https://doi.org/10.5194/acp-16-6681-2016, 2016.

Kistler, R., Collins, W., Saha, S., White, G., Woollen, J., Kalnay, E., Chelliah, M., Ebisuzaki, W., Kanamitsu, M., Kousky, V., van den Dool, H., Jenne, R., and Fiorino, M.: The NCEP-NCAR 50Year Reanalysis: Monthly Means CD-ROM and Documentation, B. Am. Meteorol. Soc., 82, 247-267, 2001.

Kobayashi, S., Ota, Y., Harada, Y., Ebita, A., Moriya, M., Onoda, H., Onogi, K., Kamahori, H., Kobayashi, C., Endo, H., Miyaoka, K., and Takahashi, K.: The JRA-55 Reanalysis: General Spec- ifications and Basic Characteristics, J. Meteorol. Soc. Jpn., 93, 5-48, https://doi.org/10.2151/jmsj.2015-001, 2015.

Krismer, T. R. and Giorgetta, M. A.: Wave Forcing of the QuasiBiennial Oscillation in the Max Planck Institute Earth System Model, J. Atmos. Sci., 71, 1985-2006, 2014.

Lawrence, B. N.: A gravity-wave induced quasi-biennial oscillation in a three-dimensional mechanistic model, Q. J. Roy. Meteorol. Soc., 127, 2005-2021, 2001.

Lindzen, R. S. and Holton, J. R.: A Theory of the quasi-biennial oscillation, J. Atmos. Sci., 25, 1095-1107, 1968.

Lott, F., Denvil, S., Butchart, N., Cagnazzo, C., Giorgetta, M. A., Hardiman, S. C., Manzini, E., Krismer, T., Duvel, J.-P., Maury, P., Scinocca, J. F., Watanabe, S., and Yukimoto, S.: Kelvin and Rossby-gravity wave packets in the lower stratosphere of some high-top CMIP5 models, J. Geophys. Res.-Atmos., 119, 21562173, 2014.

Manzini, E., Giorgetta, M. A., Esch, M., Kornblueh, L., and Roeckner, E.: The Influence of Sea Surface Temperatures on the Northern Winter Stratosphere: Ensemble Simulations with the MAECHAM5 Model, J. Climate, 19, 3863-3881, 2006.

Maruyama, T.: Large-scale disturbances in the equatorial lower stratosphere, J. Meteorol. Soc. Jpn., 45, 169-199, 1967.

Morgenstern, O., Braesicke, P., O’Connor, F. M., Bushell, A. C., Johnson, C. E., Osprey, S. M., and Pyle, J. A.: Evaluation of the new UKCA climate-composition model Part 1: The stratosphere, Geosci. Model Dev., 2, 43-57, https://doi.org/10.5194/gmd-2-43-2009, 2009.

Newman, P. A., Coy, L., Pawson, S., and Lait, L. R.: The anomalous change in the QBO in 2015-2016, Geophys. Res. Lett., 43, 87918797, 2016.

Onogi, K., Tsutsui, J., Koide, H., Sakamoto, M., Kobayashi, S., Hatsushika, H., Matsumoto, T., Yamazaki, N., Kamahori, H., Takahashi, K., Kadokura, S., Wada, K., Kato, K., Oyama, R., Ose, T., Mannoji, N., and Taira, R.: The JRA-25 Reanalysis, J. Meteorol. Soc. Jpn., 85, 369-432, 2007.

Osprey, S. M., Gray, L. J., Hardiman, S. C., Butchart, N., Bushell, A. C., and Hinton, T. J.: The Climatology of the Middle Atmosphere in a Vertically Extended Version of the Met Office's Climate Model. Part II: Variability, J. Atmos. Sci., 67, 3637-3651, 2010.

Osprey, S. M., Gray, L. J., Hardiman, S. C., Butchart, N., and Hinton, T. J.: Stratospheric Variability in Twentieth-Century CMIP5 Simulations of the Met Office Climate Model: High Top versus Low Top, J. Climate, 26, 1595-1606, 2013.

Osprey, S. M., Butchart, N., Knight, J. R., Scaife, A. A., Hamilton, K., Anstey, J. A., Schenzinger, V., and Zhang, C.: An unexpected disruption of the atmospheric quasi-biennial oscillation, Science, https://doi.org/10.1126/science.aah4156, online first, 2016.

Pascoe, C. L., Gray, L. J., Crooks, S. A., Juckes, M. N., and Baldwin, M. P.: The quasi-biennial oscillation: Analysis using ERA-40 data, J. Geophys. Res.-Atmos., 110, D08105, https://doi.org/10.1029/2004JD004941, 2005.

Plumb, R. A. and McEwan, A. D.: The Instability of a Forced Standing Wave in a Viscous Stratified Fluid: A Laboratory Analogue of the Quasi-Biennial Oscillation, J. Atmos. Sci., 35, 1827-1839, 1978.

Reed, R. J.: The structure and dynamics of the 26-month oscillation in tropical latitudes, in: Proceedings of the International Sym- 
posium on the Dynamics of Large-Scale Processes in the Atmosphere, Russian Academy of Science, Moscow, 376-387, 1967.

Reed, R. J., Campbell, W. J., Rasmussen, L. A., and Rogers, D. G.: Evidence of a downward-propagating, annual wind reversal in the equatorial stratosphere, J. Geophys. Res., 66, 813-818, 1961.

Rienecker, M. M., Suarez, M. J., Gelaro, R., Todling, R., Bacmeister, J., Liu, E., Bosilovich, M. G., Schubert, S. D., Takacs, L., Kim, G.-K., Bloom, S., Chen, J., Collins, D., Conaty, A., da Silva, A., Gu, W., Joiner, J., Koster, R. D., Lucchesi, R., Molod, A., Owens, T., Pawson, S., Pegion, P., Redder, C. R., Reichle, R., Robertson, F. R., Ruddick, A. G., Sienkiewicz, M., and Woollen, J.: MERRA: NASA's Modern-Era Retrospective Analysis for Research and Applications, J. Climate, 24, 3624-3648, 2011.

Saha, S., Moorthi, S., Pan, H.-L., Wu, X., Wang, J., Nadiga, S., Tripp, P., Kistler, R., Woollen, J., Behringer, D., Liu, H., Stokes, D., Grumbine, R., Gayno, G., Wang, J., Hou, Y.-T., Chuang, H.Y., H.-Ming, Juang, H., Sela, J., Iredell, M., Treadon, R., Kleist, D., van Delst, P., Keyser, D., Derber, J., Ek, M., Meng, J., Wei, H., Yang, R., Lord, S., van den Dool, H., Kumar, A., Wang, W., Long, C., Chelliah, M., Xue, Y., Huang, B., Schemm, J.-K., Ebisuzaki, W., Lin, R., Xie, P., Chen, M., Zhou, S., Higgins, W., Zou, C.-Z., Liu, Q., Chen, Y., Han, Y., Cucurull, L., Reynolds, R. W., Rutledge, G., and Goldberg, M.: The NCEP Climate Forecast System Reanalysis, B. Am. Meteorol. Soc., 91, 1015-1057, 2010.

Scaife, A. A., Butchart, N., Warner, C. D., Stainforth, D., Norton, W., and Austin, J.: Realistic quasi-biennial oscillations in a simulation of the global climate, Geophys. Res. Lett., 27, 3481-3484, 2000.

Schmidt, H., Rast, S., Bunzel, F., Esch, M., Giorgetta, M., Kinne, S., Krismer, T., Stenchikov, G., Timmreck, C., Tomassini, L., and Walz, M.: Response of the middle atmosphere to anthropogenic and natural forcings in the CMIP5 simulations with the Max Planck Institute Earth system model, J. Adv. Model. Earth Syst., 5, 98-116, 2013.

Shibata, K. M. and Deushi, M.: Long-term variations and trends in the simulation of the middle atmosphere 1980-2004 by the chemistry-climate model of the Meteorological Research Institute, Ann. Geophys., 26, 1299-1326, 2008a.

Shibata, K. M. and Deushi, M.: Simulation of the stratospheric circulation and ozone during the recent past (1980-2004) with the MRI chemistry-climate model, in: CGER's Supercomputer Monograph Report, vol. 13, 154 pp., NIES, Japan, 2008b.

SPARC CCMVal: SPARC Report on the Evaluation of ChemistryClimate Models, sPARC Report No. 5, WCRP-132, WMO/TDNo. 1526, 2010.
Takahashi, M.: Simulation of the stratospheric quasi-biennial oscillation using a general circulation model, Geophys. Res. Lett., 23, 661-664, 1996.

Takahashi, M.: Simulation of the Quasi-Biennial Oscillation in a general circulation model, Geophys. Res. Lett., 26, 1307-1310, 1999.

Tian, W. and Chipperfield, M. P.: A new coupled-chemistry model for the stratosphere: The importance of coupling for future O3climate predictions, Q. J. Roy. Meteor. Soc., 131, 281-303, 2005.

Uppala, S. M., Kållberg, P. W., Simmons, A. J., Andrae, U., Bechtold, V. D. C., Fiorino, M., Gibson, J. K., Haseler, J., Hernandez, A., Kelly, G. A., Li, X., Onogi, K., Saarinen, S., Sokka, N., Allan, R. P., Andersson, E., Arpe, K., Balmaseda, M. A., Beljaars, A. C. M., Berg, L. V. D., Bidlot, J., Bormann, N., Caires, S., Chevallier, F., Dethof, A., Dragosavac, M., Fisher, M., Fuentes, M., Hagemann, S., Hølm, E., Hoskins, B. J., Isaksen, L., Janssen, P. A. E. M., Jenne, R., Mcnally, A. P., Mahfouf, J.-F., Morcrette, J.-J., Rayner, N. A., Saunders, R. W., Simon, P., Ster, A., Trenberth, K. E., Untch, A., Vasiljevic, D., Viterbo, P., and Woollen, J.: The ERA-40 re-analysis, Q. J. Roy. Meteor. Soc., 131, 29613012, 2005.

Wallace, J. M. and Kousky, V. E.: Observational evidence of Kelvin waves in the tropical stratosphere, J. Atmos. Sci., 25, 900-907, 1968.

Wallace, J. M., Panetta, R. L., and Estberg, J.: Representation of the Equatorial Stratospheric Quasi-Biennial Oscillation in EOF Phase Space, J. Atmos. Sci., 50, 1751-1762, 1993.

Warner, C. D. and McIntyre, M. E.: An ultrasimple spectral parametrization for nonorographic gravity waves, J. Atmos. Sci., 85, 1837-1857, 2001.

Watanabe, S. and Kawatani, Y.: Sensitivity of the QBO to Mean Tropical Upwelling under a Changing Climate Simulated with an Earth System Model, J. Meteorol. Soc. Jpn., 90A, 351-360, 2012.

Watanabe, S., Hajima, T., Sudo, K., Nagashima, T., Takemura, T., Okajima, H., Nozawa, T., Kawase, H., Abe, M., Yokohata, T., Ise, T., Sato, H., Kato, E., Takata, K., Emori, S., and Kawamiya, M.: MIROC-ESM 2010: model description and basic results of CMIP5-20c3m experiments, Geosci. Model Dev., 4, 845-872, https://doi.org/10.5194/gmd-4-845-2011, 2011.

World Climate Research Programme: WCRP Coupled Model Intercomparison Project - Phase 5, Special Issue of the CLIVAR Exchanges Newsletter, 15, 2010. 